\title{
Research on Construction of Red Cultural Theory System with the Chinese Characteristics
}

\author{
Xiaoming Qiao \\ Journal Editorial Department, Yunnan Normal University, Kunming \\ 650092, Yunnan China
}

\begin{abstract}
Although the red culture is a conventional concept, its significance is far beyond the culture itself. Previous researchers due to problems such as knowledge structure, it has been difficult to adapt to the discipline integration development request. This needs to be based on the reality of today's China, with innovative thinking to construct red cultural science theory system with Chinese characteristics, make the party history culture, historical and cultural revolution and construction and political science, economics, culture, communication and management disciplines such as digest, luxuriant turned and elite culture to popular culture, theory research and practice, in order to solve the contradiction between supply and demand and play a theoretical guidance for practice better.

Keywords: red cultural, theory system, Chinese characteristics
\end{abstract}

\section{The red cultural studies need to upgrade urgently}

The so-called big knowledge is able to grasp the pulse of the times, to solve practical problems to be answered major theoretical problems, rather than fuss or big problems; the so-called real knowledge, is the development of social practice much-needed knowledge, rather than scratch boots or waste pen and paper.

In recent years, with the rapid development of red tourism in the country to adapt to the red culture has become the academic community, and even the whole society a hot spot, and made some research results. However, it can not meet the 
needs of the development of practice. The contradiction between theoretical research and practical demand supply is still very outstanding.

Xi Jinping 517 speech proposed to build the Chinese characteristics of the philosophy and social science system, so that "really understand the truth" is not the direction of fans, "five face"; "not forget the original, absorbing foreign and future-oriented" Inheritance, nationality, originality, the times, systematic, professional), reflecting the people's dominant position. This provides a guiding principle and great courage for our theoretical innovation.

In fact, as early as the thirties of last century, the Chinese Communists represented by Comrade Mao Zedong, created Marxism-Leninism with Chinese characteristics --- Mao Zedong Thought; and promptly and clearly put forward:

After decades of hard and tortuous efforts to continuously resist and exclude interference from both sides, and from the old society and the invasion of foreign ideas and culture, once established a healthy, clean and healthy social and cultural ecological environment. It is because of these achievements, for us to further enhance the research level and laid a solid foundation. But this task is not completed, and in the current become very prominent.

Since the reform and opening up, with the rapid development of social economy and culture, especially in the Internet technology is increasingly developed, changing people's thinking, work and lifestyle, we continue to explore and achieve positive results, but also facing huge Cultural development opportunities and challenges: the economic field of neo-liberalism, history and culture of nihilism, etc. caused by the loss of ideals and beliefs, indifferent, marginalization of mainstream ideology.

Red culture, although it is a convention concept, but there have been decades, we can not give the theoretical interpretation of the scientific system! For this cultural phenomenon of the reasons for the lack of profound research and understanding of this cultural form can not recognize from the heart, used to the kind of machinery in the past, the dogma of self-appreciation of the "lonely wild whine", can not be sober, face up to the times Conditions of change and practical development of the reality!

Especially in recent years, under the new historical conditions, with the rise of red tourism, red song singing adaptation, began to focus on cultural and political, economic integration, for the party history culture industrialization such as red tourism, red film and television industry provides historical data Support, but also for the revolutionary history and culture to expand a greater display space.

However, the problem is very obvious: First, most of them are confined to a certain area of revolutionary history research, to the extent of carving (even fine to fictional), and not completely out of the study; the second is to grasp the macro, Systematic, theoretical enough; third is for the history of nihilism, especially the ugly revolutionary historical figures, events, arbitrarily raise the stains of the characters, "Fan Wei Feng" cultural phenomenon is not timely effective and powerful counterattack to face up to listen! There is also a fatal cause of academic power to become slaves! In real life, many people have the right to have the so-called "academic" status. 
On the red cultural studies, some basic theoretical research is not deep enough, such as red culture in the end is what? How to clarify the relationship with the party history culture, revolutionary history and culture, history and culture? How to coordinate the history and reality of the relationship between advanced culture? As a cross, integration of new knowledge, systematic research is not enough, ignore the essence of red culture connotation, especially ignore culture, communication in red culture research status and role, and thus failed to timely and accurate answer practice put forward of the major theoretical and practical problems, there is a lack of theoretical research and practical needs of the contradiction. In other words, has not yet achieved the party history culture, revolution and construction of history and culture of this high on the small minority, elite, elegant culture to the public, national, popular culture --- red culture gorgeous turn!

Since ancient times, our intellectuals have "ambition for the world, for the people of life, for the Holy following the secret, for the eternal peace" ambition and tradition. All ideals and ambitions of the philosophical and social science workers should be the forefront of the times, through the changes in ancient and modern, the pioneer of thinking, and actively for the party and the people of academic theory, offer advice and suggestions, to assume the glorious mission of history. The angle determines the height and the way of thinking determines the way out. The times call for new energy to the greatest extent possible for the public recognition of the theoretical system of energy generated! This requires us to profoundly grasp the spirit of General Secretary Xi Jinping's speech and the series of speeches about red culture and red tourism with the guidance of dialectical materialism and historical materialism.

It is necessary and feasible to construct the theoretical system of red culture, and it is summarized as follows:

The first is to carry forward the socialist core values, the second is the need to build advanced socialist culture, the third is the need to build a spiritual home, the other is to clean up and create a healthy atmosphere is the need for social environment; The need to strengthen the cultural soft power; 6 is the creation of modern Chinese philosophy with the characteristics of the social science theory system needs; 7 is to resist the needs of various non-ferrous cultural invasion; 8 is to enhance the positive energy to achieve China's dream booster!

Second, China's old and new democratic revolution, the socialist revolution and construction, the great practice of reform and opening up, providing a rich, steady stream of red cultural resources; Third, the dialectical Materialism and historical materialism provided the guidance of ideological methodology; Fourth, the study of Chinese red culture has achieved initial and fruitful results; Fifth, red culture in recent 10 years under the new historical conditions booming; Six is the 18th National Congress since Party style and social atmosphere as a whole have been fundamentally reversed; seven is to Xi Jinping, general secretary of the Party Central Committee attaches great importance to solve the contradiction between theory and practice, the time is ripe. 


\section{The Chinese characteristics of red culture}

Human civilization can not be separated from the inheritance. Any new social culture, in the past, the accumulation of diversified social and cultural, critically absorb the beneficial ingredients and thrive.

For this new term, which has emerged in recent years, there are different understandings among the different researchers: if we think that the red culture is the culture of the Chinese Communist Party, the communist culture, the revolutionary culture, the new-democratic culture and the old revolutionary culture, "Political culture, revolutionary history and culture, etc., these generalizations are not generalized or narrow. In the end what is the red culture? Red positive solution - the definition of red is essential!

The political meaning of "red": red is often used to symbolize the revolution in politics and the left, the socialist countries used to express communism. Marx's favourite colour; the first red flag of the Paris Commune Lenin and Trotsky formed the Red Guards later the former Soviet Red Army, then people will be "red" as a revolutionary or political consciousness, the red regime, the red base symbol of. At the beginning of the Chinese revolution, the "Red Army" (also known as the "Soviet Area", the Soviet regime under the leadership of the Communist Party of China), the "White Zone" (the Kuomintang regime) "And" white terror "of the points. The Red Army, the Red Regime, the Red Flag, the Red Scarf after the founding of the People's Republic of China, the Red Army, the Red Army, the Red Army, the Red Army, Red, red, classic, red song, etc., the red also symbolizes the revolution and progress (such as the red).

Series of red to the people of China is an important revelation: red is not a single, pure, but there are differences in the degree of concentration, but all have their own value. Such as the revolutionary tradition: the revolution in China since modern times, the peasant revolution, the bourgeois revolution (including reform), the proletarian revolution (including the new democratic revolution, the socialist revolution, reform and opening up is essentially a revolution); then patriotism : A communist patriotism and internationalism combined; a basic masses of patriotism and socialism combined with the love of the socialist motherland; love the Chinese nation against foreign aggression of the national spirit; uneven, there are layers, which Both in line with historical facts, but also in line with real life.

The new-democratic revolution in China is led by the proletariat, and the people and the masses seize power under the people's democratic dictatorship, based on the alliance of workers and peasants. This shows that all classes and strata participating in the revolution and political power have red elements, Is the social progress and development of positive energy. Of course, the Communist Party is a vanguard, is the core of leadership, history and culture is the core, leading the other progressive culture, which is Chinese characteristics. Therefore, the red culture, not pure red is red, but there is a hierarchy system.

Culture is pluralistic and historic. The multiplicity of social life determines the cultural pluralism; the essence of culture is the problem of values. We say that red culture that advanced culture, with "advanced" modified culture, is the ideology and values of the problem. The culture that can reflect and adapt to the 
development requirements of advanced productive forces, the culture that represents and protects the fundamental interests of the overwhelming majority of the people, and the culture that represents the direction of Chinese culture is the advanced culture. Advanced standards are a historical concept which can not be separated from the social and historical conditions.

\section{The construction of red culture theory system}

Systematic theory tells us that $1+1$ is greater than 2, may also be less than 2; participation in the more harmonious, the better. Social impact is multifaceted, to prevent mutual offset, we should have a system of thinking, red culture, systematic, systematic is a must, fragmentation is not desirable.

\subsection{The object and content of red cultural studies}

Research object: Red culture is a study of modern red culture phenomenon and its occurrence and development law as the object of study. It is a comprehensive, involving the political, economic, cultural, historical, military, management, geography, society, psychology, journalism and other disciplines of the humanities. The main contents of the research include the study of the interrelationships and relations among the various levels or subsystems of the red culture, and the interrelationships and relations between cultural phenomena and economic and social phenomena. It reveals the overall structure, characteristics and development of red culture law, to show these cultural phenomena behind the common nature and universal law. The specific contents include: the rise and prosperity of red culture, basic connotation, basic structure, evolution law, environmental analysis, brand expression, construction subject, construction project, internationalization, nationalization, innovation and development; red culture time and space, text Symbol and symbol, inheritance and education, change and conflict, the mainstream and tributary.

\subsection{The basic structure of the theoretical system of red culture}

Red cultural theory and system, the chapter, section, purpose, sub-purpose, including the basic theory of red culture, red culture and historical evolution, red cultural connotation and manifestation, red culture, red culture, red culture and industry The red cultural research, the internationalization of the red culture, the red cultural innovation and development, etc .; each chapter includes a number of sections, such as the first chapter, including the concept of red culture, composition and characteristics of the red culture of the object, content, Red cultural research status and other sections. Each section includes a number of objectives, such as the first chapter of the second chapter, the conditions of red culture, including the red cultural production of social factors, cultural factors of red culture, red culture generated regional natural factors; It is divided into a number of sub-head, such as the fifth chapter of the second section of the red 
cultural transmission of media culture transmission, including newspaper culture, film and television culture, broadcast culture, network culture, image culture, sports culture, consumer culture, food culture, clothing, cultural transmission, tourism, cultural communication and other sub-head.

\section{Accurately grasp the red cultural transmission orientation}

Red tourism is the core and soul of red tourism; tourism is only one of the ways to spread red culture, not the only; red tourism, red culture has a unique advantage and the law and the law; Art, also has its limitations. Therefore, the red culture is a multi-channel transmission. Communication to tell the true effect, can not do show form. Leave the red culture, tourism innovation is only a formal pattern of renovation.

Red cultural transmission is the red culture disseminated by the red culture as the information content, purposeful and consciously integrated use of various media, carriers and means of communication to disseminate the spirit of the red culture, effectively reach the target, and make it into the receiver Their own value orientation and behaviour. It is a form of cultural communication aiming at helping the rights and interests of the recipients to establish the correct value orientation and behaviour. The process of communication is a process of people sharing high-quality red cultural resources and accepting enlightenment. Communication and culture are inseparable, there is no culture of communication and there is no non-dissemination of culture. The factors influencing the communication effect are composed of human factors, information factors, media factors and environmental factors. The media factor mainly refers to the red cultural transmission media, that is, the red cultural information carrier; environmental factors mainly refer to the red cultural dissemination of the external. The construction of red cultural transmission effect system can be explored and constructed around the above four aspects.

In order to achieve good communication effect, we must adhere to the "three close to" principle, vivid principle, to facilitate the acceptance of principles, the principle of hierarchy. At the same time grasp the characteristics of the red culture of communication that is the main body of the broad, diversified channels, the direction of the dominant, distinctive purpose, innovative way. Especially to grasp the characteristics of innovation, in the concept, system, content, form and other aspects of innovation, by creating the brand, cultivate the object model, diversified theme development, three-dimensional presentation and media linkage to create "chain" effect; to build a long-term mechanism of full participation. According to the continuous development of social practice, red cultural history and reality to achieve the red cultural theory and practical application of the combination of the red culture to better serve the people and serve the great practice of building socialism with Chinese characteristics, services in the party and the country's overall situation.

In order to achieve better dissemination of results, in the current major efforts to curb red tourism on the social and cultural negative effects. In particular, such 
as unofficial history of the impact of history; do not respect the historical facts; joking history to take heroes to open rinse; by "red" to enjoy and other issues squandered. The second is to overcome the red cultural broadcast by the rebellious psychology. In the face of the passive psychological disposition, the communicator should be guided to promote it to the positive aspects. To overcome the broadcast of the rebellious psychology, but also to seriously absorb the errors have occurred. For example, the red culture is simply equivalent to the revolutionary culture, red cultural form of a single rigid, content and form are always the same old, full of preaching, high above the subject confined to a certain small space, and sometimes even from the real blindly overthrowing the theme, led directly from the era, can easily cause people's rebellious psychology; In addition, the red culture in some places into a utility to achieve utilitarian needs of the tool. These misunderstandings are mainly due to the red culture in real life function positioning is not accurately grasp the result, so in practice must appear on the level of errors. Should be realistic and objective expression of history, rather than deliberately packaged for publicity. At the same time, the red cultural communication should also scientifically distinguish the level of the receiver, insist on the unity of advanced nature and broadness, and strive to minimize the rebellious psychology of the participants. The third is to overcome the red tourism in the "run etiquette" negative effects. There is no essential difference between the process of people's ideological education and the "pilgrimage": they will maintain a "sacred" state in the process of instilling advanced thoughts, and they will be full of passion and passion. Once the indoctrination is over, the state will gradually disappear. Lei Feng activities have been criticized for many years, "Lei Feng uncle very hard, March to April to go" phenomenon is the strong evidence. The only way to sustain and expand the original educational outcomes is to repeatedly stimulate and develop feedback mechanisms. Such as the red tourist area chain, the Union operating in the implementation of the points system to stimulate the tourists once again choose the red area as the next tourist destination. At the same time by the tourist souvenirs, bonus characteristics of red resources and history, with a certain collection of value brochures to "stimulate" tourists to return to their places after repeated after taste.

\section{References}

[1][3]Xi Jinping: Speech at the Symposium on Philosophy and Social Sciences, Xinhua News Agency, 18 May, 2016 http://news.xinhuanet.com/politics/201605/18/c 1118891128.htm

[2][4]Xu Renli: "Introduction to the development of red tourism", China Tourism Press, pp.87- 91, 2013

[5] Fan Qiong: Red tourism in the study of cultural transmission, University of Science and Technology of China, 12(10), pp. 18- 20, 2012

[6] Li Haibo: On the value of red cultural transmission and strategy, Jiangxi Normal University, 9(6), pp.58- 61, 2011 